\title{
VISCOSITY AND COMPOSITION OF SOLUTIONS DERIVED FROM RABBIT VITREOUS HUMOUR*
}

\author{
BY \\ S. A. BORUCHOFF $\dagger$ AND A. M. WOODIN \\ Medical Research Council Ophthalmological Research Unit, Institute of Ophthalmology \\ University of London
}

THERE are three kinds of macromolecular substance in the vitreous humour: fibrous material, a viscous mucopolysaccharide, and soluble protein. The first, the residual protein, has many properties in common with collagen (Pirie, Schmidt, and Waters, 1948). The second, hyaluronic acid, has been characterized by Meyer and Palmer (1934) and shown to be a polymer of glucuronic acid and $\mathrm{N}$-acetyl glucosamine. The last, the soluble protein, has some characteristics in common with serum proteins (Varga and Balazs, 1954; Brunish, Rowen, and Irvine, 1955), but the identity of the two has yet to be proved.

These materials are present in very small amounts. Ox vitreous, for example, contains only about $0 \cdot 12$ per cent. colloids. Since the colloids are so dilute, it appeared probable that the stability of the gel was due not to water-binding by the isolated molecules but to their interaction to produce a network. We have obtained evidence to support this from a study of ox vitreous humour (Woodin and Boruchoff, 1955). Thus when ox vitreous is solubilized by high-speed stirring, the resultant liquid exhibits anomalous viscosity. Anomalous viscosity is the dependence of the viscosity on the forces applied to the liquid and it is a sign of the tendency of the liquid to form a gel. We found that the anomalous viscosity of ox vitreous is due to interaction between the hyaluronic acid and the residual protein, soluble protein playing little part in the process. The interaction is not due to specific chemical bonds but may be explained in terms of the size and charge of the particles.

It will be shown in this paper that rabbit vitreous humour has a much smaller concentration of hyaluronic acid and a somewhat larger concentration of residual protein than ox vitreous humour. Therefore some preliminary experiments in vitro on the factors determining the stability of rabbit vitreous humour were carried out.

The stability in vivo was also of interest. Von Sallman (1948) showed that injections of hyaluronidase into vitreous humour caused an inflammatory response and facilitated the movement of injected red blood cells. Pirie

*Received for publication October 7, 1955.

Postdoctorial Fellow of the National Institute of Neurological Disease and Blindness, U.S. Public Health Service 
(1949), using a polysaccharide disaggregation test, found that hyaluronidase caused disaggregation of vitreous hyaluronic acid in vivo. Planten and Hoppenbrouwers (1954) concluded that hyaluronidase does not liquefy the vitreous humour. We have accordingly investigated the effect of hyaluronidase injections in vivo on the stability of the vitreous gel.

\section{Methods}

In vivo Experiments.-Adult rabbits of either sex under nembutal anaesthesia were used. Only one eye was injected, the other serving as a control. Injections of $0.1 \mathrm{ml}$. physiological saline or of solutions of the testicular hyaluronidase "Rondase" (Evans Medical Supplies) containing $300 \mu \mathrm{g}$./ml. were made aseptically. The animals were killed with nembutal at different times after the injections and the eyes were observed in the slit lamp. They were then removed and cut equatorially, and the vitreous was allowed to fall free, the anterior attachments being severed with a scalpel.

A rough impression of the state of the vitreous body could be formed at this stage, permitting a distinction to be made between a normal vitreous, with only a few drops of liquid but a large gelatinous mass, and a liquid vitreous with little gelatinous material but much fluid. A quantitative measure of the fluidity of the vitreous was made at this stage by observing the time required for $0.4 \mathrm{ml}$. of filtrate to form from a vitreous humour suspended in a funnel of silk gauze (30 mesh/inch).

The filtrate was collected in calibrated tubes containing some solid sodium diethyl-dithiocarbamate. The latter was added to inactivate the $\mathrm{Cu}^{++}$-ascorbic acid system of aqueous humour which is capable of depolymerizing hyaluronic acid (Bárány and Woodin, 1955). The filtrate was shaken for 15 minutes and a known volume dialysed in the cold for 24-48 hrs against $0.2 \mathrm{M} \mathrm{NaCl}, 0.016 \mathrm{M}$ $\mathrm{NaH}_{2} \mathrm{PO}_{4}, 0.034 \mathrm{M} \mathrm{Na}_{2} \mathrm{HPO}_{4}, p \mathrm{H}$ 7. The solution was then filtered through a porosity-4 sintered glass filter (a.p.d. 5-10 microns), the volume adjusted to that of the solution before dialysis, and the viscosity measured in the horizontal viscosimetre.

Experiments on Pooled Rabbit's Vitreous.-The material was prepared from rabbit eyes which had been stored in the frozen state. An equatorial cut was made while the eye was frozen and the sclera peeled away from the solid vitreous which was then washed with saline, blotted, and thawed.

A solution could be made from the thawed vitreous by stirring in a blendor fitted with steel blades rotating at 14,000 r.p.m. This process was carried out at $0{ }^{\circ} \mathrm{C}$. and in the presence of about $5 \mathrm{ml} .0 \cdot 1$ per cent. sodium diethyl-dithio-carbamate for each $100 \mathrm{ml}$. vitreous. The liquid was centrifuged at 2,500 r.p.m. for 15 minutes and the sediment discarded. The supernatant will be known as the " homogenate".

Filtrates of this homogenate were made by passage though a porosity- 4 sintered glass filter (a.p.d. 5-10 microns) or through gradcol membranes (a.p.d. 440 or $190 \mathrm{~m} \mu$ ).

A preparation made from eyes which had not been frozen did not differ from the above. 


\section{Analytical Methods}

Viscosity Measurements.-These were made at $30^{\circ} \mathrm{C}$. The horizontal viscosimeter was attached to a constant pressure appáratus permitting shear rates of 35-500 $\mathrm{sec}^{-1}$. The capillary had the dimensions, radius $0.0195 \mathrm{~cm}$., length $29.8 \mathrm{~cm}$., and the flow time for $0.048 \mathrm{ml}$. water was $28.4 \mathrm{sec}$. at a pressure of $70 \mathrm{~mm} . \mathrm{H}_{2} \mathrm{O}$. The shear rate was calculated from the formula:

$$
\beta=\frac{8 V}{3 \pi y^{3} t}
$$

$V$ being the volume flowing through the capillary, radius $y$, in time $t$. No correction for kinetic energy was necessary. Relative viscosity was obtained by comparing the flow time of vitreous with that of saline at the same shear rate.

The Couette viscosimeter used in the experiments on pooled rabbit vitreous had the following dimensions: diameter of outer cylinder $16 \mathrm{~mm}$., and diameter of inner cylinder $12 \mathrm{~mm}$. The inner cylinder was immersed to a depth of $10 \mathrm{~cm}$. in $10 \mathrm{ml}$. liquid.

Ultraviolet Absorption Measurements.-These were made in a Unicam spectrophotometer. The optical densities were corrected for scatter, and refer to a 1-cm. light path.

Hydroxyproline.-This was determined by the method of Neuman and Logan (1950). For blanks, vitreous samples were subjected to the entire process with the exception of the final heating at $70^{\circ}$.

Hexosamine.-This was determined by the reaction of Elson and Morgan (1933). Hydrolysis was in $5.8 \mathrm{~N} \mathrm{HCl}$ for $6 \mathrm{hrs}$ at $105^{\circ}$. Standards were carried through the hydrolysis procedure.

Hyaluronic Acid.-Concentrations were calculated from the hexosamine values. So obtained the values are maximal, since soluble protein can contain combined hexosamine.

\section{Results}

Table I describes the effect of hyaluronidase or saline injection on the state of the vitreous humour. Normal and saline-injected eyes differed

TABLE I

EFFECT OF HYALURONIDASE AND 'SALINE INJECTIONS ON THE VITREOUS HUMOUR OF RABBITS

\begin{tabular}{|c|c|c|c|c|}
\hline \multirow{2}{*}{ Material } & \multirow{2}{*}{$\begin{array}{l}\text { No. of } \\
\text { Eyes* }\end{array}$} & \multirow{2}{*}{$\begin{array}{l}\text { Mean Number of Seconds } \\
\text { for } 0.4 \mathrm{ml} \text {. to } \\
\text { pass through Gauze }\end{array}$} & \multicolumn{2}{|c|}{ Mean Relative Viscosity } \\
\hline & & & $\beta=300-400$ & $\beta=100-200$ \\
\hline $\begin{array}{ll}\text { Normal vitreous } \quad \ldots \\
\end{array}$ & $\begin{array}{l}5 \\
6\end{array}$ & 297 & $\overline{1 \cdot 15}$ & $\overline{1 \cdot 19}$ \\
\hline $\begin{array}{ccc}\text { Vitreous after saline in- } \\
\text { jection } & \ldots & \ldots\end{array}$ & $\begin{array}{l}3 \\
5\end{array}$ & 242 & $\overline{1 \cdot 13}$ & $\overline{1 \cdot 19}$ \\
\hline $\begin{array}{c}\text { Vitreous after hyaluron- } \\
\text { idase injection } \quad \ldots\end{array}$ & $\begin{array}{r}5 \\
3 \\
12\end{array}$ & $\begin{array}{l}6 \\
6 \\
-\end{array}$ & $\begin{array}{l}1.04 \\
1.03 \\
1.03\end{array}$ & $\begin{array}{l}1.08 \\
1.08 \\
1.09\end{array}$ \\
\hline
\end{tabular}

* The eyes were excised 1-2 days after the injection. 
little, but the vitreous from eyes into which hyaluronidase had been injected flowed through the gauze forty to fifty times more rapidly than those from control eyes. The corresponding filtrates differed four-fold in their viscosities. The latter difference can account for only one-quarter of the difference of the rate of flow through gauze. It can therefore be concluded that the gel is liquefied by hyaluronidase. This received confirmation from visual inspection of the vitreous body on opening the globe. In every case in which hyaluronidase had been injected, the structure of the vitreous had been noted as " mostly fluid " or " grossly fluid ", whereas the normal or saline-injected eyes had been described as "grossly gel". Vitreous from a single animal killed 30 days after the hyaluronidase injection had the same flow time through gauze, and the filtrate the same viscosity as from those which survived 1-2 days.

We confirm the observations of previous authors that hyaluronidase causes an inflammatory reaction, but injections of $30 \mu \mathrm{g}$. caused the appearance of only a few cells in the anterior vitreous. No animals which showed aqueous flare are included in this report.

Table II describes the hydroxyproline content of rabbit vitreous and its derivatives. Collagen is the only protein which contains hydroxyproline in significant amounts (Neuman and Logan, 1950). Since residual protein is similar to collagen, the hydroxyproline content has been used as a measure of collagen concentration. Only a little of the hydroxyproline-containing material is solubilized on homogenization and that is retained by a porosity4 filter. The results obtained from the ox are included for comparison.

TABLE II

HYDROXYPROLINE CONTENT OF VITREOUS HUMOUR AND ITS DERIVATIVES

\begin{tabular}{|c|c|c|c|}
\hline & Material & $\begin{array}{l}\text { Hydroxyproline } \\
\text { Content }(\mu \mathrm{g} . / \mathrm{ml} .)\end{array}$ & $\begin{array}{c}\text { Calculated Collagen Content }+ \\
\mu \mathrm{g} . / \mathrm{ml} \text {. }\end{array}$ \\
\hline Rabbit & $\begin{array}{l}\text { Whole Vitreous } \\
\text { Homogenate } \\
\text { Porosity-4 Filtrate }\end{array}$ & $\begin{array}{l}14 \\
1 \cdot 5-2 \\
0 \cdot 2\end{array}$ & $\begin{array}{l}128 \\
13 \cdot 6-18 \cdot 2 \\
1 \cdot 82\end{array}$ \\
\hline$O x^{*}$ & $\begin{array}{l}\text { Whole Vitreous } \\
\text { Homogenate } \\
\text { Porosity-4 Filtrate }\end{array}$ & $\begin{array}{l}8-10 \\
5-8 \\
1-2\end{array}$ & $\begin{array}{c}73-91 \\
45-73 \\
9 \cdot 1-18 \cdot 2\end{array}$ \\
\hline
\end{tabular}

* Results taken from Woodin and Boruchoff (1955).
+ Collagen content calculated by assuming 11 per cent. hydroxyproline.

Table III (opposite) shows the effect of ultrafiltration on the viscosity and composition of the porosity-4 filtrate. Some hyaluronic acid is removed by a membrane with a pore size $190 \mathrm{~m} \mu$ and there is a corresponding decrease in the relative viscosity. As the optical density at $280 \mathrm{~m} \mu$ indicates, soluble protein is removed by both 440 and $190 \mathrm{~m} \mu$ membranes, but there is little change in the viscosity on passage through the former. In the Couette viscosimeter the relative viscosity of homogenate varied little in the 
TABLE III

EFFECT OF ULTRAFILTRATION ON VISCOSITY AND COMPOSITION OF POOLED RABBIT VITREOUS HUMOUR

\begin{tabular}{|c|c|c|c|}
\hline Material & $\begin{array}{l}\text { Relative Viscosity* } \\
\qquad\left(\beta=50 \text { sec. }^{-1}\right)\end{array}$ & $\begin{array}{c}\text { Hyaluronic Acid } \dagger \\
(\mu \mathrm{g} . / \mathrm{ml} .)\end{array}$ & $\begin{array}{c}\text { Optical } \\
\text { Density } \ddagger \text { at } 280 \mathrm{~m} \mu\end{array}$ \\
\hline Homogenate... & $1 \cdot 20$ & $26 \cdot 4$ & $0 \cdot 53$ \\
\hline Porosity-4 Filtrate ... & $1 \cdot 16$ & $26 \cdot 4$ & $0 \cdot 49$ \\
\hline $440 \mathrm{~m} \mu$. Membrane & $1 \cdot 14$ & $24 \cdot 6$ & 0.33 \\
\hline $\begin{array}{l}190 \mathrm{~m} \mu . \\
\text { Filtrate }\end{array}$ & 1.06 & $17 \cdot 0$ & $0 \cdot 15$ \\
\hline
\end{tabular}

* Viscosity measured in Couette viscosimeter.

+ Hyaluronic acid calculated from hexosamine determinations.

shear rate range of 10 to $50 \mathrm{sec}^{-1}$ There was some evidence for anomalous viscosity at lower shear rates, but the magnitude of the deflections was too small to permit a definite conclusion.

\section{Discussion}

The combined-hydroxyproline content of rabbit vitreous humour corresponds to a concentration of $0.13 \mathrm{mg}$. $/ \mathrm{ml}$. of a collagen-like protein. This is about 40 per cent. higher than that of the ox, but in contrast to the ox vitreous, little of the hydroxyproline-containing material is solubilized by homogenization. The hyaluronic acid concentration of the rabbit vitreous is about one-tenth that of the ox. These facts may be relevant to the conclusion we have made that the stability of suspensions of residual protein depends on the presence of hyaluronic acid (Woodin and Boruchoff, 1955).

The viscosity of solutions derived from rabbit vitreous is far less than that of solutions from the ox. This is to be expected from the lower concentration of solubilized hydroxyproline and of hyaluronic acid. However the effects of filtration are similar. Filtration through a porosity-4 filter and a $190 \mathrm{~m} \mu$. membrane successively reduce the viscosity. Analysis of the solutions reveals that the porosity-4 filter removes the residual protein and the 190-m $\mu$. membrane removes some hyaluronic acid. A membrane of larger pore size has little effect on the viscosity but removes some soluble protein.

The in vivo experiments confirm the findings of Pirie (1948) that hyaluronidase injections cause depolymerization of hyaluronic acid in the vitreous humour. Further they demonstrate that the gel structure is broken down by the enzyme. This is consistent with the conclusion we have drawn that the gel structure results from the interaction of the residual protein and the hyaluronic acid. 


\section{Summary}

Rabbit vitreous humour contains less hyaluronic acid but more residual protein than ox vitreous. Little of the residual protein is brought into solution on homogenization. Filtration of homogenized rabbit vitreous through porosity-4 glass filters and through $190-\mathrm{m} \mu$. gradcol membranes progressively reduce the viscosity of the solution. The former removes residual protein and the latter some hyaluronic acid. Injections of hyaluronidase liquefy vitreous gel through disaggregation of the hyaluronic acid.

We wish to thank Mr. G. Cook for his technical assistance.

\section{REFERENCES}

BÁRÁNy, E. H., and Woodin, A. M. (1955). Acta physiol. scand., 33, 257.

Brunish, R., Rowen, J. W., and IRvine, S. R. (1955). Trans. Amer. ophthal. Soc., 52, 369.

Elson, L. A., and Morgan, W. T. J. (1933). Biochem. J., 27, 1824.

MeYer, K., and Palmer, J. W. (1934). J. biol. Chem., 107, 629.

Neuman, R. E., and Logan, M. A. (1950). Ibid., 184, 299.

PIRIE, A. (1949). British Journal of Ophthalmology, 33, 678. SCHMIDT, G., and WALTERS, J. W. (1948). Ibid., 32, 321.

Planten, J. T., and HoppenbrouWers, R. (1954). Ophthalmologica (Basel), $127,117$. Von Sallmann, L. (1948). Arch. Ophthal. (Chicago), 39, 401.

Varga, L., and Balazs, E. A. (1954). Amer. J. Ophthal., 38, Suppl. (July, Pt. II), 29.

Woodin, A. M., and Boruchoff, S. A. (1955). J. biophys. biochem. Cytol., 1, 489. 